\title{
Continuous improvement processes using Lean Management tools. A case study
}

\author{
Luminița Pârv ${ }^{1, *}$ \\ ${ }^{1}$ Transilvania University of Braşov, Department of Manufacturing Engineering, Mihai Viteazu No.5, \\ Braşov, Romania
}

\begin{abstract}
The paper describes how Lean Management may be applied in the university setting to improve the management processes. The correlation of didactic, educational and research activities with the stakeholders needs is one of the main objectives of the university. In this respect, an indicator used to analyse a university, for the purposes of fulfilling its mission, respectively for the purposes of streamlining its didactic and scientific activity, is related to the number of graduates on the labour market, acting in their area of specialization. This work presents a best practice of Lean Management at Transilvania University of Brasov, Romania.
\end{abstract}

\section{Introduction}

Lean practices are the tools and methods commonly associated with the Toyota production system [1]. The main Lean principles are Continuous Improvement and Respect for People.

A study of use of continuous improvement to achieve instructional improvement and instructional technology improvement with the help of an example of a high school which applied lean framework and resulted at use of screen capture technology was presented by Flumerfelt and Green, in [2].

The conclusion presented the ratio of time allocated to task/relational activities, the ratio of time allocated to passive/active learning, the amount of time allocated to new learning opportunity, the amount of time allocated to individualization, and the amount of time allocated to differentiation.

Lean management is defined as a three levels management system focused on creating value for customers and eliminating waste, unevenness and unreasonableness using the scientific method [3].

The tactical level is based on the following five principles [2]:

- Specify Value -it is necessary to specify what adds value from the end customer's perspective, so that all the non-value activities can be identified and removed; in fact for most production processes only a small part of the total production time and effort adds value for the end customer;

- Identify the Value stream-identify all activities that do not aggregate any value to the final product;

${ }^{*}$ Corresponding author: luminita.parv@unitbv.ro 
- Create Flow - promote continuous flow in the process by eliminating wastes;

- Customer Pull - respond to customer demand; produce what customers' wants at the right time;

- Pursue Perfection - continually remove wastes, striving for a perfect process.

At the operational level, the practices and tools are: Value stream mapping, $5 \mathrm{~S}$, Kaizen, One piece flow, JIT, TQM and Six Sigma.

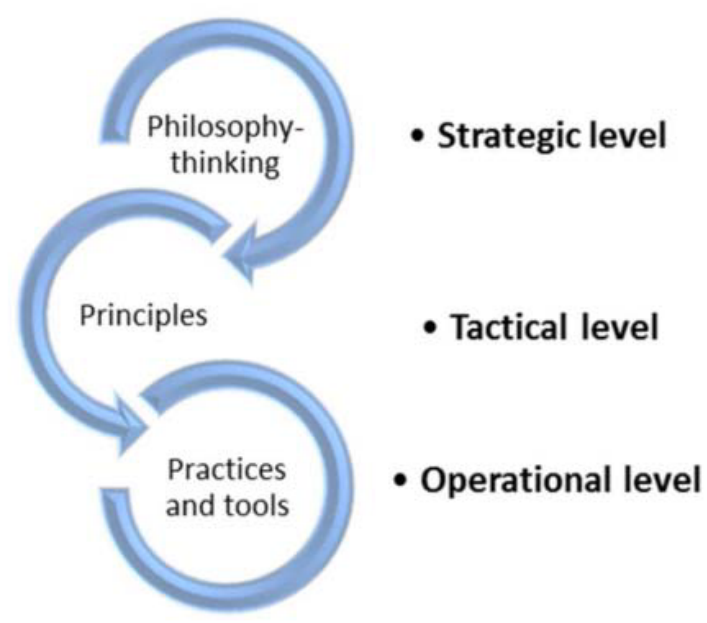

Fig. 1. Levels of the Lean Management $[4]$.

Lean education is the application of Lean principles and practices to the education field

\section{Lean in higher education}

The purpose of Lean teaching parallels the purpose of Lean management $[1,2,5]$, as used in organizations, which is to improve the value of goods and services (higher education) for end-use customers (students, payers, employers and society) [1] started to implement concepts of Lean teaching, tools, and processes in a college with three functions teaching, research, and service.

Emiliani $[6,7]$ used kaizen process for ten courses contained in a part-time executive MS degree program in management and the conclusion was that Kaizen is an effective process for improving graduate business school courses and the value proposition for students.

Doman [5] used lean principles and practices to improve university's grade change administrative processes in higher education through learning experience involving undergraduate students working as a team to identify waste and redesign process in a seminar course. The authors have emphasized that team used process mapping and value stream mapping lean tools to predominantly focus on four wastes namely delay, over processing or incorrect processing, correction and knowledge disconnection.

According to [3, 4, 8 - 10], the end-use customers in higher education will be students, employers and society.

The strategic management plan of the Transilvania University formulates the mid- and long-term aims of our university, by considering the actual and future necessities of the working market. 
Through the perspective of the bounds established with the economic environment, the strategy aims to determine how the university can achieve the best competitive impact for industry-university collaboration.

The team management proposes, in order to improve the educational process, the implementation of the Lean Together strategy in learning-together in practice.

A SIPOC (Suppliers/Input/Process/Output/Customer) diagram is used by the team to identify all relevant elements of the educational process improvement project before work begins.

The SIPOC tool answers at these questions:

- Who supplies inputs to the process?

- What specifications are placed on the inputs?

- Who are the true customers of the process?

- What are the requirements of the customers?

Table 1. The implementation of the strategy is accomplished through projects developed together with the economic environment

\begin{tabular}{|c|c|c|c|c|}
\hline Supplier & Input & Process & Output & Customer \\
\hline $\begin{array}{c}\text { Higher } \\
\text { education } \\
\text { providers }\end{array}$ & Students & Orientation & $\begin{array}{c}\text { Successful } \\
\text { graduates }\end{array}$ & $\begin{array}{c}\text { Academic } \\
\text { organisations }\end{array}$ \\
\hline $\begin{array}{c}\text { Employers } \\
\text { from } \\
\text { industry }\end{array}$ & $\begin{array}{c}\text { Certificated } \\
\text { faculties }\end{array}$ & $\begin{array}{c}\text { Practical } \\
\text { placement }\end{array}$ & $\begin{array}{c}\text { Unemployed } \\
\text { graduates }\end{array}$ & $\begin{array}{c}\text { Government } \\
\text { Organizations }\end{array}$ \\
\hline & Learning & Projects & Industries \\
\hline
\end{tabular}

\section{Together in learning-together in practice as a PDSA cycle}

In order to apply the Together in learning-together in practice the Plan-Do-Study-Act cycle will be used.

Following the conceptual framework's logic of PDSA, the process of improvement application started with the Plan phase, in which a detailed program was designed $100 \%$ student-centred (costumer focused).

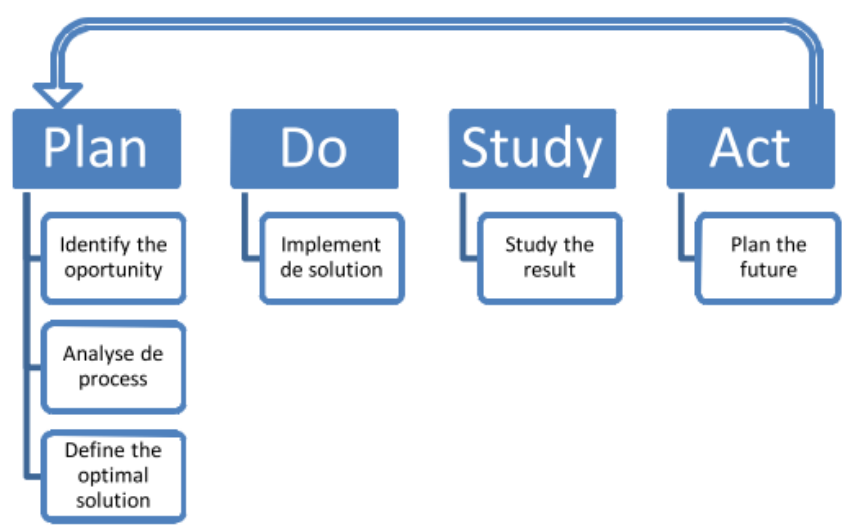

Fig. 2. The PDSA phases 


\subsection{Plan phase}

Plan part suppose opportunity identifier, process analyse, optimal solution development.

Together in learning-together in practice are materialized in two projects:

- Organization of an annual conference, where graduating students of the BSc or MSc programs, who want to participate, have the possibility to present in front of company representatives the diploma or dissertation project. The Graduates in Front of Companies (AFCO) bring face to face our alumni and the representatives of the economic and sociocultural environment; specifically, the students may enrol for this conference and may present, as poster, significant aspects of diploma paper;

- Furthermore, the university has developed the project Podium of the Companies. This way, in the largest complex of our institution, in the central lobby, it launched a project enabling the main regional companies to present themselves, to discuss with the Transilvania university students and teaching staff, to submit technical and research subjects, to propose diploma-project themes, to offer part-time or full-time jobs. Thereby, by enhanced dialogue, the interests of both parties (university and economic environment) are intertwined and the graduates' chances to succeed on the labour market substantially increase.

The project's objective is to improve the cooperation with the socio-economic environment and the regional integration, by:

- Attracting the socio-economic environment in the process of determining the skills needed for higher education graduates in order to integrate them as quickly as possible within the labor market;

- Enhancing the transfer of innovation from academia to the socio-economic environment;

- Developing the cooperation between the academic and socio-economic environment by developing joint investment projects / programs, research, internship or volunteer programs

- Attracting prestigious specialists from the socio-economic environment in the educational process;

- Promoting the principles of sustainable development in the provision of higher education services;

Proposed activities:

- the promotion of partner companies' activities in which the university's students can be involved;

- presenting to the students the characteristics of the partner companies and the opportunity that the students are recruited by these companies;

- other activities proposed by the companies that respect the objectives of the project in agreement with the university structures responsible for the relationship with the companies.

\subsection{Do phase}

The Do phase of the continuous improvement cycle comes next. During this phase, the projects were implemented (2012-starting date for AFCO, 2013-starting date for PC).

\subsection{Study phase}

The third phase of the PDSA cycle is the validation (study) phase. During this phase, university gets to know the evaluation process in a Lean oriented approach. The evaluation of the Together in learning-together in practice strategy was carried out on the platform of the INFO-HE project. 
The study encompassed quantitative, survey data obtained from questionnaire-based surveys (with graduates and employers) from 2010 and 2014 graduates.

Table 2. Option- Projects proposed by the companies

\begin{tabular}{|c|c|c|c|c|c|}
\hline & & \multicolumn{2}{|c|}{2010} & \multicolumn{2}{|c|}{2014} \\
\hline & & $\begin{array}{l}\text { Absolute } \\
\text { frequency }\end{array}$ & $\begin{array}{l}\text { Relative } \\
\text { frequency }\end{array}$ & $\begin{array}{l}\text { Absolute } \\
\text { frequency }\end{array}$ & $\begin{array}{l}\text { Relative } \\
\text { frequency }\end{array}$ \\
\hline \multirow{8}{*}{$\begin{array}{l}\text { Projects } \\
\text { proposed } \\
\text { by the } \\
\text { companies }\end{array}$} & $\begin{array}{c}1- \\
\text { Strongly } \\
\text { Disagree }\end{array}$ & 4 & 10 & 25 & 10.04 \\
\hline & 2 & 8 & 20 & 37 & 14.86 \\
\hline & 3 & 8 & 20 & 54 & 21.69 \\
\hline & 4 & 7 & 17.5 & 60 & 24.1 \\
\hline & $\begin{array}{c}5- \\
\text { Strongly } \\
\text { Agree }\end{array}$ & 13 & 32.5 & 73 & 29.32 \\
\hline & Total: & 40 & & 249 & \\
\hline & Average & \multicolumn{2}{|c|}{3.42} & \multicolumn{2}{|c|}{3.48} \\
\hline & $\begin{array}{l}\text { Standard } \\
\text { deviation }\end{array}$ & \multicolumn{2}{|c|}{1.48} & \multicolumn{2}{|c|}{1.49} \\
\hline
\end{tabular}

In order to assess the effectiveness of the projects implemented by Transilvania University of Brasov, the chapters on personal development and professional career included specific questions aiming at measuring the usefulness of the graduates' skills specific to the field of studies followed.

The first set of questions relates to the teaching methods used in university. As an example: C9. To what extent have been used the following teaching - learning methods within the license program you graduated in our university?

The results were present in Table 2. and Figure 3.

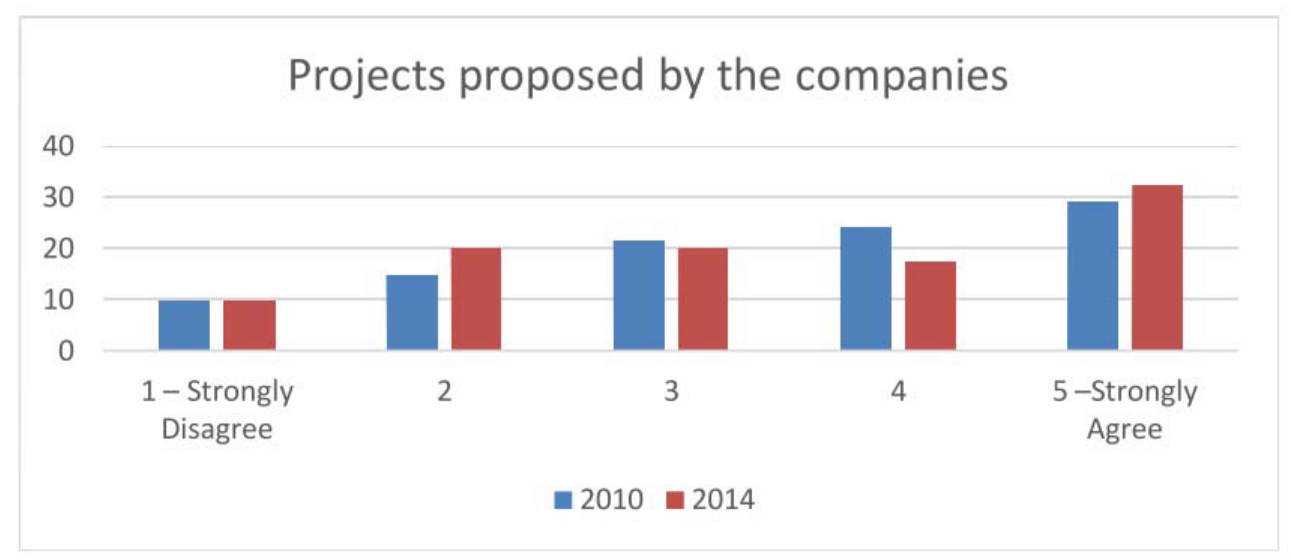

Fig. 3. Evolution of the projects proposed by the companies 


\subsection{Act phase}

Each quarter, the PDSA cycle allows generating the Act phase: the opportunity to improve the educational process.

Starting from the Lean project objective, which is to correlate the academic offer and the learning outcomes with the employment requirements using the Lean methodology.

$29 \%$ of the respondents (graduated in 2014) are currently working in a position which corresponds to the study program they have graduated from.

The cooperation with the economic and socio-cultural community knew a real improvement lately at Transilvania University of Brasov the correlation between the companies' needs and students didactical and research activities, being one of the main objectives considered by executive management team at Transilvania University. In this respect, a preliminary study on applying Lean Management was carried out for the university.

According to the survey of 2010 graduates, during the first 6 months from graduation, $13.4 \%$ of graduates were hired in a corresponding domain.

The question in the questionnaire is: F1. Which of the following would suit best your situation within the first six months after graduation?

The results below refer to promotion of 2014 .

Table 3. Survey results at the question F1

\begin{tabular}{|c|c|c|c|}
\hline & $\begin{array}{c}\text { No of } \\
\text { people who } \\
\text { answered } \\
\text { the } \\
\text { question }\end{array}$ & $\begin{array}{c}\text { Frequency (\%) of } \\
\text { the total no of people } \\
\text { (\% is over 100\% } \\
\text { because it is a } \\
\text { multiple choice } \\
\text { question) }\end{array}$ & $\begin{array}{c}\text { Frequency (\%) of } \\
\text { total responses }\end{array}$ \\
\hline $\begin{array}{c}\text { I work in a field that corresponds } \\
\text { to the license program I graduated }\end{array}$ & 104 & 42.62 & 28.34 \\
\hline I work in a different field & 53 & 21.72 & 14.44 \\
\hline $\begin{array}{c}\text { I continued to work where I have } \\
\text { already worked }\end{array}$ & 50 & 20.49 & 13.62 \\
\hline I opened my own business & 6 & 2.46 & 1.63 \\
\hline I performed an internship & 15 & 6.15 & 4.09 \\
\hline I begun to work as a volunteer & 12 & 4.92 & 3.27 \\
\hline $\begin{array}{c}\text { I enrolled in Master's or other } \\
\text { postgraduate university courses }\end{array}$ & 88 & 36.07 & 23.98 \\
\hline I enrolled in a new college \\
(undergraduate)
\end{tabular}

The identified improvements were mapped with standard Lean tools from manufacturing.

The improvements and changes that were and are being made are centered on the PDSA improvement cycle and aligned with the students' needs. 


\section{Conclusion}

Following stakeholders' feedback, the university management team standardises the good practices oriented towards the Lean philosophy, in other words, towards continuous improvement.

Table 4. Continuous improvement using Lean tools

\begin{tabular}{|c|c|}
\hline $\begin{array}{c}\text { Improvement } \\
\text { opportunity }\end{array}$ & Improvement made \\
\hline PLAN & $\begin{array}{c}\text { First, a general frame goal was established, oriented by the Together } \\
\text { in learning-together in practice }\end{array}$ \\
\hline DO & Accomplishing projects \\
\hline STUDY & $\begin{array}{c}\text { The evaluation have been made with the implication of the main } \\
\text { stakeholders }\end{array}$ \\
\hline ACT & $\begin{array}{c}\text { Given the results of the evaluation, the existing projects will improve } \\
\text { and new projects will be implemented }\end{array}$ \\
\hline
\end{tabular}

As such, the correction cycle is presented in a continuous way each quarter, in that same order of ideas. Positive results were obtained. This can be achieved with a strong industryacademia relationship grounded on a multitude of partnerships (Project-Based learning, internships, final projects, capstone projects) that provide students and faculty with real life projects, following what many authors have been advocating.

We hereby acknowledge the structural funds project POSDRU 155/1.2/S/141278 for providing the software tool used in this work.

\section{References}

1. S. Flumerfelt, G. Green, G., EdTechnSoc, 16 (1) (2013)

2. J. K. Liker, The Toyota Way - 14 Management Principles from the World's Greatest Manufacturer (2004)

3. J. Antony, IntJProdPerfManag, 64(6) (2015)

4. J. Antony, IntJProdPerfManag, 63(2) (2014)

5. M.S. Doman, QualAssurEd, 19(3) (2011)

6. M.L. Emiliani, QualAssurEd, 13(1) (2005)

7. M.L. Emiliani, QualAssurEd, 12(4) (2004)

8. R. Stasiak-Betlejewska, M. Kaye, M. Dyason, K. Stachova, ERE, 767 (2014)

9. J. Sujanova, P. Gabris, M. Licko, P. Pavlenda, R. Stasiak-Betlejewska, 13th EuConfKnowManag, 1-2, 1135 (2012)

10. R. Ulewicz, R. Kucęba, EcManag, 8(1) (2016) 